\title{
The Effect of Competence, Work Discipline and Motivation of Employee Performance in the General Secretariat of the Ministry of Trade Jakarta
}

\author{
Denok Sunarsi ${ }^{1}$, Jasmani ${ }^{2}$, Eni Puji Astuti ${ }^{3}$, Waluyo Jati ${ }^{4}$, Ali Maddinsyah ${ }^{5}$ \\ Aidil Amin Effendy ${ }^{6}$, Irfan Rizka Akbar ${ }^{7}$, Arga Teriyan ${ }^{8}$ \\ Department of Management, Faculty of Economic, Universitas Pamulang, Banten, \\ Indonesia

\begin{abstract}
\{denoksunarsi@unpam.ac.id'1,dosen01770@unpam.ac.id²,dosen00807@unpam.ac.id², dosen00565@unpam.ac.id ${ }^{4}$, alimaddinsyah@unpam.ac.id ${ }^{5}$, aidi100967@unpam.ac.id ${ }^{6}$,
\end{abstract} \\ dosen02461@unpam.ac.id ${ }^{7}$, terrybasingse@gmail.com $\left.{ }^{8}\right\}$
}

\begin{abstract}
Competence, work discipline and motivation are assumed to have an important role in a good company. Identification of the influence of competence, work discipline and motivation on employee performance at the Secretariat General of the Ministry of Trade of DKI Jakarta. Explanatory research with a sample size of 96 respondents as a method of data collection. Statistical analysis techniques are regression test and correlation. The results showed that competence. This study is proposed to find out aspects of competence related to employee performance and also emphasize the aspects of discipline and motivation that have an impact on performance, especially at the Secretariat General of the Jakarta Department of Commerce and the results of the research are expected to broaden the literature of management, especially in the field of human resources.
\end{abstract}

Keywords: Competence, Work Discipline, Motivation, Employee Performance.

\section{Background}

Human resources are a component that can not be separated in an organization, the importance of human resources components can determinethe achievement of a goal of an organization, it can not be denied that the objective of an organization will not materialize without the active role of human resources in it. And of course this will impact on the output of its work. After more than 80 years of national trading governed by The Netherlands Colonial Heritage Product Bedrijf Sreglementerings Ordonnantie (BO) in 1934, Indonesia finally has a trade law. After passing the long process, through the Plenary Meeting in February 2014 the House of Representatives (DPR) approved and authorized the Draft of the Law (Line) trade to the Law of the Republic of Indonesia no. 7 Year 2014 on Trade (Trading Law). How theTrade Act is able to generate expectations for the government, all business actors, producers, and consumer of the homeland as well as able to answer global challenges in the middle of free trade.

From the coordination side between the Ministry/Institution including business actors, the government has issued various policies contained in the Presidential Instruction Instruments (Inpres) no. 5/2008 on the focus of the economy and inpres program no.11/2011 on the 
implementation of the print blue of the economic community of ASEAN. The Inpres is intended as a guideline for the agency both the center and regional. In addition, it is also formed by the Presidential Working Unit in the development and controlling of construction (UKP4) aimed at monitoring the government's move. The government has also issued Inpres No.6 of 2014 on the increase in national competitiveness in order to face the Economic Community of ASEAN and Kepres, 37 of 2014 on the National Committee of Preparation of the ASEAN Economic Community established on September 1, 2014. The National Committee is coordinated by the Ministry of Coordinator of the Economic Equipment's with members consisting of central and local governments, academics from various universities, as well as business actors (KADIN, APINDO, HIPMI, etc.).

Related to the main task of the Secretariat General of Trade, which is organizing coordination of the task, couching and giving of administrative support to all organizational units in the Trade Ministry that has the liability directly reporting it to the Director General of Trade. An organization can work effectively if management functions such as planning, organizing, motivation, discipline and supervision are well functioning, as well as the supporting elements are available and meet the requirements. One of the most important elements that can support the company's way is human resources (employees). The main key that the success of the company is competent human resources from various fields and abilities of employees, so that achieving company goals will be easily achieved, when the human resources are good. An employee who has high and good performance can support the achievement of goals and objectives that have been established by an organization.

The Presidential Instruction (Inpres) Number 7 of 1999 on the Accountability of Government Agency performance requires every Government Agency to account for the implementation of its tasks and functions based on a strategic planning and including the management. The accountability is reported to the mandate, the leadership of each agency, supervisory institution and accountability assessment, and eventually submitted to the President. The report illustrates the performance of government agencies through a system accountability performance of the Government Agency (SAKIP). Running the function as the implementation of the task, coaching and administrative support to all organizational units in the environment of Trade Ministry by improving transparent and accountable public services, for the application of bureaucratic reform implementation.

Bureaucratic reform in Indonesia provides an overview that most of the process of bureaucracy reform has not been successful. One interesting thing is that it is mostly the area led by individual reformists can be able to show a change of good bureaucracy (the Ministry of Utilization of State Apparatus, 2013). This suggests that discipline, good competence will spur and encourage the spirit of bureaucratic apparatus to perform well in accordance with the organization wants. According to Hasibuan (2012) "Disciplication is a consciousness and willingness of people to comply with applicable regulations. Good employee discipline can reflect how much the employee's responsibility will work. This can encourage the passion of work so that the organization's goal can be achieved. Attitudes and values are an invisible that emphasizes the power to encourage individuals to behave in achieving goals. In addition, motivation can also be interpreted as an individual impulse to action because they want to do it, if a person is motivated then they will make a positive choice to do something because they can satisfy their desires.

According to Maslow (2012) "each individual has a hierarchical-based need of the most basic levels to the highest level. If the need at the lowest level is met, there will be another higher requirement. Basically motivation can spur employees to achieve productivity or performance ". Motivation is also one of the factors that can support the achievement of maximum 
performance, according to Stephen P. Robbins (source: Tenth's edition of organizational behavior, 2006: 243) defines motivation as a process that participates in determining the intensity, direction, and persistence of individuals in the effort to achieve the goal. Furthermore, in the implementation of accountability in the environment of Trade Ministry needs to be considered the principles (a), the commitment of leadership and the entire staff, (b) the strengthening of the system, which ensures the use of resources in accordance with the regulations,(c) demonstration level of achievement of goals and objectives,(d)orientation on achieving vision, mission and results and benefits, and(e) objectivity, transparency, accuracy, and innovation as catalyst to change management in a more advanced direction.

Performance increasing on the other hand cannot be done without any good management. The management should be a cycle of stages of planning, implementation, monitoring and evaluation. The result of evaluation performance became a feedback for the next planning stage. Thus, performance management is required for performance enhancements, thereby awakening the process of working-oriented process and the optimal results. In its performance all the elements in the organization have the obligation to realize vision and mission relating to the forward view concerning where government agencies should be brought and directed to work consistently, exist, anticipatory, innovative, and productive. The vision implanted in each organizational element will be a (shared vision) that is able to direct and move all agencies and something that is carried out or implemented by government agencies, As a description of the vision that has been set. With a mission statement expected all members of the organization and interested parties can know and figure out the existence and role of government agencies in the implementation of government.

Performance evaluation is one of the embodiments of the accountability of the government agency, it can be known clearly as the achievement of results, progress and constraints found in the implementation of programs andactivities can be assessed and studied (lesson learned) for being improved in the future. Another side, evaluation of performance accountability is systemic activity analysis, the giving of value, appreciation and introduction of problems, and the provision of solutions to the problems found for the purpose of improving performance and accountability work units. Based on several factors that can affect employee performance, entitled: "The effect of competence, work discipline and motivation of employee performance on the secretary of General Trade Jakarta".

\section{Literature review}

\section{1 Competency}

According to Sutrisno (2012) defines "competence is a blend of skills, knowledge, creativity and positive attitudes towards certain work embodied in performance". In this study the indicators used include: knowledge, understanding, ability, value and attitude. Literature Review.

\subsection{Work discipline}

Hasibuan (2012) defines "Work Discipline is a consciousness and a willingness to observe all corporate regulations and social applicable". In this study the indicators used include: objectives and abilities, exemplary thing, recompense, justice, sanctions and punishment. 


\subsection{Motivation}

According to Handoko (2009) defines "motivation is a set of good strength that comes from within or out of the person who is pushing to start behaving in working with the format, direction, intensity and a certain period of time". In this study the indicators used include: motivation of self-interest, the motivation of obtaining material, motivation of employment.

\subsection{Performance of employee}

According to Hasibuan (2012) defines "performance is the work result of each employee to be able to contribute positively to the company/agency". In this study the indicators used include: work performance, discipline, creativity, cooperation, responsibility.

\section{Research Methods}

The sample 96 secretary of the Secretariat General of Jakarta Trade Department. Samplingmaking technique in this research is sample saturated, where all population members are made as sample. Total 96 respondents in filling out the research questionnaire. This type of associative research aims to determine the relationship between the independent and dependent variables. The data analysis used is the classic assumption test, regression, and hypothesis testing.

\section{The Result of research}

\subsection{Descriptive Analysis}

Descriptive analysis shows the distribution of score data for each variable shown in table 1

Table 1. The result of statistic prescriptive analysis Descriptive Statistics

\begin{tabular}{|c|c|c|c|c|c|}
\hline $\mathbf{N}$ & & Minimum & Maximum & Mean & Std. Deviation \\
\hline Competence (X1) & 96 & 35 & 56 & 45.07 & 4.288 \\
\hline Work discipline (X2) & 96 & 38 & 56 & 46.24 & 4.139 \\
\hline Motivation (X3) & 96 & 36 & 56 & 46.02 & 4.415 \\
\hline Employee performance (Y) & 96 & 39 & 56 & 47.03 & 4.079 \\
\hline Valid N (Listwise) & 96 & & & & \\
\hline
\end{tabular}

The Competency Score gets 35 results on the minimum variant and 56 on the maximum variant with a standard deviation of 4.288 and a score of 4.62 , respectively. Furthermore, the work discipline variable obtained a minimum variance of 38 and a maximum variance with a standard deviation of 4.139 and 56 with a rating score of 4.62 . Motivation obtained a minimum variance of 36 and a maximum variant of 56 with a standard deviation of 4.415 with a rating score of 4.60. Employee performance obtained a minimum variance of 39 and a maximum variance of 56 with a standard deviation of 4.075 with a rating score of 4.70 . 


\subsection{Verification}

\section{a) Regression Analysis}

This regression test is intended to know the change of dependent variable if independent variables change. The results of the following tests:

Table 2. Results of multiple regression testing

\begin{tabular}{|c|c|c|c|c|c|c|}
\hline \multicolumn{7}{|c|}{ Coefficients $^{\mathrm{a}}$} \\
\hline \multicolumn{4}{|c|}{ Model Unstandardiz Coefficients } & \multirow{2}{*}{$\begin{array}{c}\text { Standardized } \\
\text { Coefficients Beta }\end{array}$} & \multirow[t]{2}{*}{$\mathbf{t}$} & \multirow[t]{2}{*}{ Sig. } \\
\hline & $\mathbf{B}$ & & $\begin{array}{c}\text { Std. } \\
\text { Error }\end{array}$ & & & \\
\hline \multirow[t]{4}{*}{1} & (Constant) & 8.271 & 4.071 & & 2.032 & .045 \\
\hline & Competence (X1) & .225 & .079 & .236 & 2.840 & .006 \\
\hline & Work discipline (X2) & .453 & .087 & .460 & 5.220 & .000 \\
\hline & Motivation(X3) & .166 & .079 & .180 & 2.111 & .037 \\
\hline
\end{tabular}

Based on the test results in the above table, obtained regression equations $=8,271+0.225 \times 1$ $+0.453 \times 2+0.166 \times 3$.

\section{b) Analysis of Correlation Coefficient}

Correlation analysis to identify the relationship between variables that influence and are influenced, so that the results of the study will show a simultaneous or partial relationship. The following test results:

Table 3. Results of competency correlation coefficient testing on employee performance.

\begin{tabular}{|c|c|c|c|}
\hline \multicolumn{4}{|c|}{ Correlations $^{b}$} \\
\hline Compet & ence (X1) & & Employee performance (Y) \\
\hline Competence (X1) & $\begin{array}{l}\text { Pearson Correlation } \\
\text { Sig. (2-tailed) }\end{array}$ & 1 & $\begin{array}{l}.505^{\pi \pi} \\
.000\end{array}$ \\
\hline Employee performance(Y) & $\begin{array}{l}\text { Pearson Correlation } \\
\text { Sig. (2-tailed) }\end{array}$ & $\begin{array}{l}.505^{\text {** }} \\
.000\end{array}$ & 1 \\
\hline
\end{tabular}

**. Correlation is significant at the 0.01 level (2-tailed).

a. Listwise $\mathrm{N}=96$

Table 4. Results of correlation coefficient testing of work discipline

\section{Correlations $^{\mathbf{b}}$}

\begin{tabular}{cccc}
\hline \multicolumn{2}{c}{ Work Discipline (X2) } & & Kinerja Pegawai (Y) \\
\hline Disiplin Kerja (X2) & Pearson Correlation & 1 & $.650^{* \pi}$ \\
& Sig. (2-tailed) & & .000 \\
Kinerja Pegawai (Y) & Pearson Correlation & $.650^{\pi \pi}$ & 1 \\
& Sig. (2-tailed) & .000 & \\
\hline
\end{tabular}

**. Correlation is significant at the 0.01 level (2-tailed).

b. Listwise $\mathrm{N}=96$

Based on the testing results obtained correlation value of 0.650 means that work discipline 
has a strong relationship to employee performance.

Table 5. The testing result of the correlation coefficient of motivation to the performance of employees.

\begin{tabular}{llcc}
\multicolumn{2}{c}{ Correlations $^{\mathbf{b}}$} & \\
\hline Motivation & (X3) & & $\begin{array}{c}\text { Employee } \\
\text { Peformance (Y) }\end{array}$ \\
\hline Motivation (X3) & Pearson Correlation & 1 & $.489^{* \pi}$ \\
& Sig. (2-tailed) & .000 \\
Employee Peformance (Y) & Pearson Correlation & $.489^{* *}$ & 1 \\
& Sig. (2-tailed) & .000 & \\
\hline
\end{tabular}

**. Correlation is significant at the 0.01 level (2-tailed).

b. Listwise $\mathrm{N}=96$

Table 6. Testing Results of correlation coefficient of competence, motivation and work discipline simultaneously on employee performance.

Model Summary

Model
R Square

a. Predictors: (Constant), Motivation (X3), Competence (X1), Work Discipline (X2)

employee performance of 0.712 categories. The strength of the relationship is based on the assumption that the discipline and motivation variables have an influence on employee performance.

\section{c) Analysis of Determination Coefficent}

The following test results:

Table 7. Results of coefficient testing of competence determination on employee performance.

\section{Model Summary}

\begin{tabular}{|c|c|c|c|}
\hline Model R & R Square & Adjusted R Square & Std. Error of the Estimate \\
\hline $.505^{\mathrm{a}}$ & .255 & .248 & 3.539 \\
\hline
\end{tabular}

Table 8. Testing Results of the coefficient of determination of discipline work on employee performance.

Model Summary

\begin{tabular}{|c|c|c|c|}
\hline Model R & R Square & Adjusted R Square & Std. Error of the Estimate \\
\hline $1.650^{\mathrm{a}}$ & .423 & .417 & 3.115 \\
\hline
\end{tabular}


Table 9. The result of testing the coefficient of motivation determination of employee performance.

Model Summary

Model R R Square Adjusted R Square Std. Error of the Estimate

\begin{tabular}{lrrr}
\hline 1 & $.489^{\mathrm{a}}$ & .239 & .231
\end{tabular}

Based on the test results obtained the determination value of 0.239 means the motivation has an impact contribution of $23.9 \%$ to employee performance.

Table 10. Testing Results of the coefficient of competence determination, work discipline, and motivation of employee performance

\section{Model Summary}

\begin{tabular}{|c|c|c|c|}
\hline Model R & R Square & $\begin{array}{c}\text { Adjusted R } \\
\text { Square }\end{array}$ & $\begin{array}{l}\text { Std. Error of the } \\
\text { Estimate }\end{array}$ \\
\hline $.712^{\mathrm{a}}$ & .507 & .491 & 2.911 \\
\hline
\end{tabular}

\subsection{Hypothesis Test}

\section{a) Partial Hypothesis Test (T test)}

Hypothesis testing as evidence of the researcher's temporary answers before conducting research. as for the proposed hypothesis

Table 11. The results of the competitive hypothesis test of employee performance

\begin{tabular}{|c|c|c|c|c|c|c|}
\hline \multicolumn{7}{|c|}{ Coefficients $^{\mathbf{a}}$} \\
\hline & \multicolumn{3}{|c|}{$\begin{array}{l}\text { Model Unstandardized } \\
\text { Coefficients }\end{array}$} & \multirow[t]{2}{*}{$\begin{array}{c}\text { Standardized } \\
\text { Coefficients Beta }\end{array}$} & \multirow[t]{2}{*}{$\mathbf{t}$} & \multirow[t]{2}{*}{ Sig. } \\
\hline & B & & Std. Error & & & \\
\hline \multirow[t]{2}{*}{1} & (Constant) & 25.358 & 3.834 & & 6.615 & .000 \\
\hline & Competence (X1) & .481 & .085 & .505 & 5.679 & .000 \\
\hline
\end{tabular}

a. Dependent Variable: Employee Performance (Y)

Based on the testing results on the table, the value of $t$ count $>\mathrm{T}$ table or $(5,679>1.986)$, thus the first hypothesis filed that there is a significant effect of the competence on employee performance accepted.

Table 12. Result of hypothesis test of work discipline on employee performance

\begin{tabular}{cccccc}
\multicolumn{6}{c}{ Coefficients } \\
\hline \multicolumn{2}{c}{$\begin{array}{c}\text { Model Unstandardized } \\
\text { Coefficients }\end{array}$} & $\begin{array}{c}\text { Standardized } \\
\text { Coefficients Beta }\end{array}$ & t & Sig. \\
\hline B & \multicolumn{3}{c}{ Std. Error } & & \\
\hline 1 (Constant) & 17.390 & 3.585 & & 4.851 & .000 \\
Work Dicipline (X2) & .641 & .077 & .650 & 8.302 & .000 \\
\hline
\end{tabular}


a. Dependent Variable: Employee Performance (Y)

Table 13. The results of the motivation hypothesis test on employee performance.

\begin{tabular}{|c|c|c|c|c|c|}
\hline \multicolumn{6}{|c|}{ Coefficients ${ }^{a}$} \\
\hline \multirow{2}{*}{\multicolumn{3}{|c|}{$\begin{array}{l}\text { Model Unstandardized } \\
\text { Coefficients }\end{array}$}} & \multirow{2}{*}{$\begin{array}{c}\text { Standardized } \\
\text { Coefficients Beta }\end{array}$} & \multirow[t]{2}{*}{$\mathrm{t}$} & \multirow[t]{2}{*}{ Sig. } \\
\hline & & & & & \\
\hline 1 (Constant) & 26.234 & 3.843 & & 6.827 & .000 \\
\hline Motivation (X3) & .452 & .083 & .489 & 5.437 & .000 \\
\hline
\end{tabular}

\section{b) The simultaneous hypothesis test (F test)}

F test is used to determine whether the simultaneous hypothesis is accepted or rejected. based on the results:

Table 14. The results of competency hypothesis tests, work disciplines and motivation of employee performance.

\begin{tabular}{lccccc}
\multicolumn{5}{c}{ ANOVA } \\
\hline Model Sum of Squares & df & Mean Square $^{\mathbf{a}}$ & F & Sig. \\
\hline 1 Regression & 801.167 & 3 & 267.056 & 31.509 & $.000^{\mathrm{b}}$ \\
Residual & 779.739 & 92 & 8.475 & & \\
Total & 1580.906 & 95 & & & \\
\hline a. Dependent Variable: Employee Performance (Y) \\
b. Predictors: (Constant), Motivation (X3), Competence (X1), work discipline (X2)
\end{tabular}

\subsection{Discussion of Research Results}

based on the analysis of independent variables such as work discipline and competence, which play an important role in improving employee performance in the company. competence as a resource in performing obligations as workers and discipline as a form of moral responsibility carried out by employees with good and effective time management. The competence and discipline of work significantly affected employee performance obtained regression equations $\mathrm{Y}=8,271+0.225 \times 1+0.453 \times 2+0.166 \times 3$, shows the contribution of influence that can be considered in improving company performance. The requirements for a good company must trigger work discipline and increase employee competence so that what is done is in accordance with their talents and abilities so that results will be maximized.

\section{Conclucion}

The amount of the contribution of both of them is $25.5 \%$, and the rest is another factor based on the $t$ test $>\mathrm{T}$ table or $(5,679>1,986)$. Furthermore, work discipline has an effect on employee performance by $42.3 \%$ based on the $t$ value $>\mathrm{T}$ table or $(8.302>1.986)$. Work discipline contribution is greater than employee competency. Furthermore, the influence of motivation on employee performance is $23.9 \%$. The effect of competence, work discipline and motivation on employee performance simultaneously is $50.7 \%$. the remaining $49.3 \%$ other factors that affect 
employee performance that can not be disclosed. Research recommendation is that there are other factors that have not been studied that can affect employee performance, so that it can be studied more deeply about the relationship between performance and other variables.

\section{Bibliography}

[1] Arikunto, Suharsimi (2014). "Prosedur Penelitian Suatu Pendekatan Praktek”. Jakarta: Rineka Cipta.

[2] Hasibuan, SP, “Dasar-dasar Perbankan”, Haji Masagung, Jakarta, 2012.

[3] Imam Ghozali (2017). "Aplikasi Analisis Multivariate Dengan Program SPSS”. Edisi Kelima. Semarang: Badan Penerbit Undip.

[4] Peraturan Menteri PAN dan RB nomor: 20 Tahun 2010 tentang Roadmap Reformasi Birokrasi

[5] Santoso, Singgih (2015). "Menguasai Statistik Multivariat". Jakarta: PT Elex Media Komputindo.

[6] Sugiyono (2017), "Metode Penelitian Administrasi : dilengkapi dengan Metode $R \& D$ ". Bandung: Alfabeta.

[7] Sunarsi, D. (2019). Seminar Sumber Daya Manusia. Tangerang Selatan: Unpam Press

[8] Sunarsi, D. (2019). The Analysis of The Work Environmental and Organizational Cultural Impact on The Performance and Implication of The Work Satisfaction. Jurnal Ilmiah Ilmu Administrasi Publik, 9(2), 113-122.

[9] Erlangga, H. (2020). The Challenges of Organizational Communication in the Digital Era. Solid State Technology, 63(4), 1240-1246.

[10] Erlangga, H., Sifatu, . W. O., Wibisono, . D., Siagian, . A. O., Salam, . R., Mas'adi, . M., Gunartin, ., Oktarini, . R., Manik, . C. D., Nani, ., Nurhadi, . A., Sunarsi, . D., Purwanto, . A \& Kusjono, . G. (2020) Pharmaceutical Business Competition in Indonesia: A Review. Systematic Reviews in Pharmacy, 11 (10), 617-623. doi:10.31838/srp.2020.10.92

[11] Gumilar, I., Sunarsi, D. (2020). Comparison of financial performance in banking with high car and low car (Study of banks approved in the kompas 100 index for the period 2013-2017). International Journal of Psychosocial Rehabilitation. Volume 24 - Issue 7

[12] Gunartin, Siagian, . A. O., Nufus, . K., Yusuf, . N., Supratikta, . H., Maddinsyah, . A., Muchtar, . A., Sari, . W. I., Sunarsi, . D., Akbar, . I. R., Arianto, . N., Purwanto, . A., Noryani, . \& Wijoyo, . H. (2020) A Systematic Literature Review of Education Financing Model in Indonesian School. Systematic Reviews in Pharmacy, 11 (10), 638-644. doi:10.31838/srp.2020.10.96

[13] Hidayat, D., Prabowo, B., \& Anwar, S. (2020). Organizational Leadership and Conflict in Human Resource Management Review. Solid State Technology, 63(6), 1372-1381.

[14] Kembara, M.D, Hanny, R., Gantina, N., Kusumawati, I., Budimansyah, D., Sunarsi, D., Khoiri, A. (2020). Scientific Literacy Profile Of Student Teachers On Science For All Context. Solid State Technology. Vol. 63 No. 6

[15] Lukiastuti, Fitri, et.al (2020). The Influence of Entrepreneur's Personal Characteristics on SMES Performance Mediated by Entrepreneurial Orientation. International Journal of Psychosocial Rehabilitation. Volume 24 - Issue 8

[16] Maddinsyah, A., Sunarsi, D., Hermawati, R., Pranoto. (2020). Analysis of location selection effect on the user decision that influcence the success of the service business of micro, small and medium enterprise (MSME) in bandung timur region. International Journal of Advanced Science and Technology. Vol. 29 No. 06

[17] Nufus, K., Supratikta, H., Muchtar, A., Sunarsi, D. (2020). Analysis of Financial Performance: Case Study of PT. X Employee Cooperative. Utopía Y Praxis Latinoamericana. Año: 25, No Extra 10, 2020, pp. 429-444

[18] Purwanto, H., Fauzi, . M., Wijayanti, . R., Awwaly, . K. U. A., Jayanto, . I., Mahyuddin, ., Purwanto, . A., Fahlevi, . M., Adinugraha, H. H., Syamsudin, . R. A., Pratama, . A., Ariyanto, . N., Sunarsi, . D., Hartuti, . E. T. K. \& Jasmani, . (2020) Developing Model of Halal Food 
Purchase Intention among Indonesian Non-Muslim Consumers: An Explanatory Sequential Mixed Methods Research. Systematic Reviews in Pharmacy, 11 (10), 396-407. doi:10.31838/srp.2020.10.63

[19] Sobarna, A., Rizal, R. M., Hambali, S., \& Sunarsi, D. (2020). Influence Make a Match Model toward Communication skills in Physical and Health Pedagogical Concept. Solid State Technology, 63(6), 1355-1363.

[20] Sobarna, A., Sunarsi, D., \& Roinadi, D. K. (2020). The Effect of Pedagogic Competence Kids Athletic toward Motivation for Elementary School. Solid State Technology, 63(6), 1364-1371.

[21] Sunarsi, D. (2020). The Influence of Supply Chain Strategy on Employee Performance on Small and Medium Business in Beringharjo Market, Yogyakarta- Indonesia. International Journal of Supply Chain Management. Vol. 9, No. 5

[22] Sunarsi, D., Rohaeni, . N., Wulansari, . R., Andriani, . J., Muslimat, . A., Rialmi, . Z., Kustini, . E., Kristianti, . L. S., Rostikawati, . D., Effendy, . A. A., Purwanto, . A. \& Fahlevi, . M. (2020) Effect of e-Leadership Style, Organizational Commitment and Service Quality towards Indonesian School Performance. Systematic Reviews in Pharmacy, 11 (10), 472-481. doi:10.31838/srp.2020.10.71

[23] Supriyadi, D., Syafitri, . L. N. H., Widodo, S. F. A., Wahidi, R., Arinta, . Y. N., Nabhan, . F., Mufid, . A., Purwanto, . A., Fahlevi, . M., Sunarsi, . D. \& Cahyono, . Y. (2020) Innovation And Authentic Leadership Of Islamic University Lectures In Faculty Pharmacy Faculty: What Is The Role Of Psychological Capital?. Systematic Reviews in Pharmacy, 11 (8), 383-393. doi:10.31838/srp.2020.8.56

[24] Suryani, N. L., Sularmi, L., Eka, P. D., Sunarsi, D., \& Maddinsyah, A. (2020). The Analysis of Career Development and Placement of Employee Performance in Pt. Global Means of Transindo in Jakarta. Solid State Technology, 63(6), 1382-1389.

[25] Syobar, K., Hardiyan, A., Romlah, O. Y., Yusup, M., \& Sunarsi, D. (2020). The Effect of Service Quality and Price on Purchase Decisions in Woodpecker Coffee in South Jakarta. Solid State Technology, 63(6), 1491-1504. 